\title{
Parásitos gastrointestinales y ectoparásitos de ungulados silvestres en condiciones de vida libre y cautiverio en el trópico mexicano
}

\section{Gastrointestinal and ectoparasites in wildlife-ungulates under captive and free-living conditions in the Mexican tropic}

\author{
José Manuel Mukul-Yervesa, María del Rosario Zapata-Escobedoa, Rubén Cornelio \\ Montes-Péreza, Roger Iván Rodríguez-Vivasa, Juan Felipe Torres-Acostaa
}

\begin{abstract}
RESUMEN
Se identificaron los parásitos gastrointestinales y ectoparásitos presentes en venados cola blanca (Odocoileus virginianus), pecarí de collar (Pecari tajacu) y venado temazate (Mazama americana) en condiciones de vida libre y cautiverio en el trópico mexicano. Se obtuvieron muestras fecales y ectoparásitos de 12 ungulados de vida libre que se cazaron para fines de subsistencia y de $\mathbf{5 5}$ ungulados en condiciones de cautiverio. Las muestras de excremento se analizaron mediante las pruebas de Flotación Centrifugada y McMaster para conocer los géneros y órdenes de parásitos que afectan a los ungulados; así como la excreción de huevos y ooquistes por gramo de excremento. Los ectoparásitos encontrados se identificaron taxonómicamente. Las muestras positivas a nematodos del orden Strongylida y protozoos del orden Eucoccidiorida se cultivaron para su identificación taxonómica a nivel de géneros. En venados cola blanca y temazate en cautiverio se identificaron los géneros Strongyloides, Trichuris, Capillaria, Mammomonogamus y Eimeria; mientras que en los pecaríes de collar los géneros Oesophagostomun, Eimeria e Isospora. En los tres ungulados de vida libre se identificó el género Strongyloides. Sólo se encontraron ectoparásitos en ungulados de vida libre, identificándose la pulga Pulex irritans y el piojo Gliricola porcelli en venados temazate y pecaríes de collar, mientras que la mosca Lipoptena sp se colectó en los venados cola blanca. La garrapata Amblyomma cajennese se encontró parasitando a las tres especies de ungulados estudiados. Se concluye que los ungulados silvestres del presente estudio estuvieron parasitados con nematodos gastrointestinales, protozoos del orden Eucoccidiorida, pulgas, piojos, moscas y garrapatas.
\end{abstract}

PALABRAS CLAVE: Ungulados, Parásitos gastrointestinales, Ectoparásitos, Venados, Pecaríes.

\begin{abstract}
Gastrointestinal parasites and ectoparasites were identified in white-tailed deer (Odocoileus virginianus), collared peccary (Pecari tajacu) and brocket deer (Mazama americana) in free-living conditions and captivity in the Mexican tropics. Twelve free-living ungulates were hunted (four white-tailed deer, three brocket deer and five collared peccaries) to obtain samples of faeces and ectoparasites. Fifty-five captive ungulates (14 white-tail deer, 16 brocket deer and 35 collared peccaries) were sampled to obtain faeces and ectoparasites. To identify the genera and order of parasites, faecal samples were analyzed by Flotation and McMaster techniques. Egg and oocyst per gram of faeces were also calculated. Ectoparasites collected from ungulates were classified to genera and species level using specific identification keys. Positive samples of nematode of the order strongylida and protozoos of the order Eucoccidiorida were cultivated and classified. In white-tailed and brocket deer the following genera of parasites were identified: Strongyloides, Trichuris, Capillaria, Mammomonogamus and Eimeria. In collared peccaries the genera Oesophagostomun, Eimeria and Isospora were identified. The flea Pulex irritans and the louse Gliricola porcelli infested brocket deer and collared peccary, while the fly Lipoptena sp was collected from white-tailed deer. The tick Amblyomma cajennese was found parasitizing the three ungulate species studied. It is concluded that wild ungulates are parasitized with gastrointestinal nematodes, protozoa of the order Eucoccidiorida, fleas, lice, flies and ticks.
\end{abstract}

KEY WORDS: Ungulates, Gastrointestinal parasites, Ectoparasites, Deer, Collared peccary.

Recibido el 28 de agosto de 2013. Aceptado el 24 de enero de 2014

a Facultad de Medicina Veterinaria y Zootecnia. Campus de Ciencias Biológicas y Agropecuarias. Universidad Autónoma de Yucatán. Km. 15.5 carretera MéridaXmatkuil. 97100 Mérida, Yucatán, México. Tel.: +52-999-9423200; Fax: +52-999-9423205. rvivas@tunku.uady.mx. Correspondencia al cuarto autor. 
La fauna silvestre de Centroamérica y el sureste de México se encuentra constituida principalmente por especies de ungulados tales como venado cola blanca (Odocoileus virginianus), pecarí de collar (Pecari tajacu) y venado temazate (Mazama americana)(1). Estas especies constituyen una importante fuente de proteína para los cazadores de subsistencia $(2,3)$. Sin embargo, los ungulados pueden estar afectados por agentes patógenos causantes de enfermedades tales como virus, bacterias, endoparásitos y ectoparásitos que afectan su salud y rendimiento productivo(4).

Prestwood y Pursglove(5) mencionan que el venado cola blanca puede albergar 32 especies de nematodos. La mayoría de ellos son no patógenos en los animales silvestres de vida libre; sin embargo, los venados en cautiverio pueden sufrir de parasitosis severas y de malnutrición $(4,6,7)$. Recientemente Pato et al(8) encontraron que en España los ciervos corzo (Capreolus capreolus) se encuentran altamente infectados con nematodos gastrointestinales (NGI) de 20 diferentes especies y que tienen el potencial de producir un efecto negativo en la salud de los animales. Por otra parte, se menciona(9) que los pecaríes de collar pueden estar parasitados por cinco especies de coccidias y cuatro especies de nematodos, pero se desconoce los efectos patológicos que causan en los animales. Además, estos ungulados pueden ser infestados por ectoparásitos tales como pulgas, piojos, moscas y garrapatas que producen daño directo en sus hospederos y transmiten agentes patógenos $(10,11)$.

En el sureste de México el número de unidades de manejo para la cría de animales de fauna silvestre (UMAs) como sistemas pecuarios va en aumento. El manejo técnico, incluyendo el sanitario de las UMAs del estado de Yucatán, México, es deficiente debido a diferentes causas, tales como el desconocimiento de los principales enfermedades que afectan a estas especies cuando son mantenidas en cautiverio(12).

El confinamiento de los ungulados en los sistemas de cautiverio ha propiciado un mayor
Wild fauna in Central America and southeastern Mexico is mainly constituted by ungulate species, such as white-tailed deer (Odocoileus virginianus), collared peccary (Pecari tajacu) and red brocket deer (Mazama americana)(1). These species are a main source of protein for subsistence hunters $(2,3)$. However, ungulates may be affected by disease causative agents, such as viruses, bacteria, endoparasites and ectoparasites that alter their health and productivity performance $(4)$.

Prestwood and Pursglove(5) mention that whitetailed deer can be the reservoir host of 32 nematode species. Most of them are nonpathogenic to free-living wild animals; however, deer in captivity may suffer from severe parasitosis and malnutrition $(4,6,7)$. Recently, Pato et al(8) found that in Spain, roe deer (Capreolus capreolus) is highly infected with 20 different species of gastrointestinal nematodes (GIN), which have the potential to cause negative effect on animal health. On the other hand, it has been mentioned(9) that collared peccaries may be parasitized by five coccidian species and four nematode species, but the pathological effects on animals are unknown. Additionally, these ungulates may be infested by ectoparasites, such as fleas, lice, flies and ticks, which cause direct damage in its hosts and transmit pathogens $(10,11)$.

In southeastern Mexico, the Wildlife Conservation, Management, and Sustainable Utilization Units (UMAs) is increasing. The technical management, including the medical aspect of UMAs in Yucatan, Mexico, has been deficient due to different causes, such as ignorance of the main diseases that affect these species when kept in captivity(12).

Ungulate containment has facilitated direct animal to animal contact; therefore, the objective of this study was to determined order, genus and/or species of GIN and ectoparasites that affect white-tailed deer, red brocket deer and collared peccary under captive and freeliving conditions in the Mexican tropic. 
contacto entre los animales y por ende a un mayor riesgo de transmisión de agentes patógenos, tales como los parásitos(4). Por tal motivo, el objetivo del presente estudio es determinar los órdenes, géneros y especies de NGI y ectoparásitos que afectan a los venados cola blanca, venados temazate y pecaríes de collar en condiciones de cautiverio y vida libre en el trópico mexicano.

El estudio se realizó en el estado de Yucatán, México que presenta un clima tropical subhúmedo con lluvias en verano. La temperatura ambiente máxima varía de 35 a $40{ }^{\circ} \mathrm{C}$ y la temperatura ambiente promedio es de $27^{\circ} \mathrm{C}$. La humedad relativa varía de 65 a $90 \%$, con promedio de $80 \%$ y precipitación pluvial anual de 1,100 $\mathrm{mm}$. Se presentan dos estaciones anuales: Iluvia (de junio a noviembre) y seca (de diciembre a mayo)(13). La geomorfología pertenece al sistema carsotectónico joven, clasificado como un paisaje geomorfológico de planicie estructural ondulada con disolución y denudación. Los suelos son principalmente de tipo litosol, rendzina y cambisol(14).

Actualmente, sólo se puede observar vegetación secundaria de selva baja y mediana caducifolia en diferentes estados de regeneración, localizada en parches entre los potreros de pastos Brachiaria brizantha (Hochst. ex A. Rich.) Stapf. y Panicum maximun (Jacq.) B. K. Simon y S. W. L. Jacobs. Dichos fragmentos están conformados por Caesalpinia gaumeri Greenm. (Fabaceae), Piscidia piscipula (L.) Sarg. (Fabaceae), Mimosa bahamensis Benth. (Fabaceae), Havardia albicans (Kunth.) Benth. (Fabaceae), Acacia gaumeri Blake (Fabaceae), Randia longiloba Hamsley (Rubiaceae), Ceiba schottii Britton y Baker (Bombacaceae), Bursera simaruba (L.) Sarg. (Burceraceae), Helicteres baruensis Jacq. (Sterculiaceae), Diospyros cuneata Standley (Ebenaceae) y Thouinia pau-cidentata Radlk (Sapindaceae), entre las especies más comunes en el estado de Yucatán(15).

La Secretaría de Medio Ambiente y Recursos Naturales de México (oficio $\mathrm{N}^{\circ}$ SGPA/DGVS/
The study was conducted in the State of Yucatan, Mexico, which has a sub-humid tropical climate with rain in the summer. The maximum environmental temperature ranges from 35 to $40{ }^{\circ} \mathrm{C}$ and the average normal environmental temperature is $27{ }^{\circ} \mathrm{C}$. Relative humidity ranges from 65 to $90 \%$, with an average of $80 \%$ and annual rainfall of $1,100 \mathrm{~mm}$. There are two annual seasons: rainy (from J une to November) and dry (from December to May)(13). The geomorphology belongs to the young karst tectonic system, classified as a geomorphological view of a plain waved with dissolution and denudation. The soil is mainly lithosol, rendzina and cambisol(14).

Currently, there is only secondary vegetation of low and medium dry deciduous brizantha pasture in different regeneration stages, located in patches between pastures of Brachiaria brizantha (Hochst. Ex A. Rich.) Stapf and Panicum maximum (Jacq.) B. K. Simon and S. W. L. Jacobs. Such fragments are constituted by Caesalpina gaumeri Greenm. (Fabaceae), Piscidia piscipula (L.) Sarg. (Fabaceae), Mimosa bahamensis Benth. (Fabaceae), Havardia albicans (Kunth.) Benth. (Fabaceae), Acacia gaumeri Blake (Fabaceae), Randia longiloba Hamsley (Rubiaceae), Ceiba schottii Britton and Baker (Bombacaceae), Bursera simaruba (L.) Sarg. (Burceraceae), Helicteres baruensis Jacq. (Sterculiaceae), Diospyros cuneata Standley (Ebenaceae) and Thouinia paucidentata Radlk (Sapindaceae), among the most common species in the state of Yucatan(15).

The Secretariat of Environment and Natural Resources of Mexico (letter $\mathrm{N}^{\circ}$ SGPA/DGVS/ 05485) authorized the biological sample collection of 12 free-living ungulates, obtained from subsistence hunting (they were not hunted exclusively for this study), undertaken by peasants from two communities in eastern Yucatan, Mexico (municipalities of Buctzotz and Cenotillo). Four white-tailed deer were hunted and five collared peccaries. These three animal species are not listed on the endangered species list, according to the NOM-ECOL-059. Samples 
05485) autorizó la colecta de muestras biológicas de 12 ungulados de vida libre, obtenidos por cacería de subsistencia (no fueron cazados exclusivamente para este estudio) ejecutada por campesinos de dos comunidades localizadas en la zona oriente del estado de Yucatán, México (municipios de Buctzotz y Cenotillo). Se cazaron cuatro venados cola blanca, tres venados temazate y cinco pecaríes de collar. Estas tres especies animales están fuera de la categoría de especies en riesgo de extinción de acuerdo a la NOM-ECOL-059 mexicana. Los muestreos de los animales de vida libre se realizaron durante la época de Iluvia (julio-agosto).

Una vez cazados, los ungulados fueron trasladados a las comunidades donde se obtuvieron muestras de excremento mediante bolsas de polietileno identificadas con la especie animal. Las muestras se transportaron a $4 \stackrel{\circ}{C}$ hasta su procesamiento coproparasitoscópico en un período no mayor a $24 \mathrm{~h}(16)$.

A cada animal se inspeccionó externamente para recolectar los ectoparásitos presentes, los cuales se transfirieron a frascos con etanol al $70 \%$. Las muestras de excremento y los ectoparásitos fueron remitidos al laboratorio de Parasitología de la Facultad de Medicina Veterinaria y Zootecnia de la Universidad Autónoma de Yucatán (FMVZ-UADY) para su análisis.

Las muestras de excremento se analizaron mediante las pruebas de Flotación Centrifugada y McMaster para estimar el número de huevos por gramo de excremento $(\mathrm{h} / \mathrm{gh})$ de nematodos y ooquistes por gramo de excremento (ooq/gh) del orden Eucoccidiorida(17). Las muestras positivas a huevos de nematodos del orden Strongylida se transfirieron a cajas de Petri para permitir la eclosión de los huevos y obtener larvas $L_{3}$ mediante la técnica de Corticelli-Lai(16). Las larvas $L_{3}$ recuperadas del cultivo se identificaron con base a sus características morfológicas y tamaño descritas por "Ministry of Agriculture Fisheries and Food (MAFF)(18). Asimismo, las muestras positivas a ooquistes from the free-living animals were taken during the rainy season (July-August).

Once hunted, the ungulates were taken to the communities, where fecal samples were obtained using polyethylene bags identified by species. Samples were transported in refrigerated containers at $4^{\circ} \mathrm{C}$ until their coproparasitoscopic study within a period no longer than $24 \mathrm{~h}(16)$.

Each animal was externally examined. All ectoparasites were removed and preserved in vials of $70 \%$ ethanol. Fecal samples and ectoparasites were processed in the Laboratorio de Patología of the Facultad de Medicina Veterinaria y Zootecnia of the Universidad Autónoma de Yucatan (FMVZ-UADY).

Fecal samples were analyzed by centrifugal flotation and McMaster's techniques, estimating the number of nematode eggs per gram of feces (EPG) and oocysts per gram of feces (OPG) of the order Eucoccidiorida(17). Samples positive to nematode eggs of the order Strongylida were transferred to the Petri dishes, allowing egg hatching and obtaining $L_{3}$ larvae by the Corticelli-Lai technique(16). $L_{3}$ larvae recovered from cultures were identified based on morphological characteristics and size described by the Ministry of Agriculture Fisheries and Food (MAFF)(18). Likewise, positive samples to Eucoccidiorida oocysts were cultivated in a $2 \%$ aqueous solution of potassium dichromate(16). The oocysts were identified in terms of genus by the number of esporozoites they presented(18).

The ectoparasites were grouped according to their morphology, cleared in $10 \%$ potassium hydroxide $(\mathrm{KOH})$ and mounted on glass slides for taxonomic identification, using an optic microscope with an objective lens at $4 X(16)$. These parasites were classified following the taxonomic keys for mites, fleas(19), flies and lice(20). The specimens were photographed and placed in the entomological collection of the Laboratorio de Patología of the FMVZ-UADY. 
de Eucoccidiorida se cultivaron en una solución acuosa de dicromato de potasio al $2 \%(16)$. Los ooquistes se identificaron en cuanto a su género por el número de esporozoitos que presentaron(18).

Los ectoparásitos se agruparon de acuerdo a su tipo morfológico, aclarados en hidróxido de potasio al $10 \%(\mathrm{KOH})$ y trasferidos a portaobjetos para su identificación taxonómica usando un microscopio óptico usando el lente de $4 \times(16)$. Los ectoparásitos se clasificaron siguiendo las llaves taxonómicas para ácaros, pulgas(19), moscas y piojos(20). Los especímenes fueron fotografiados y depositados en la colección entomológica del laboratorio de Parasitología de la FMVZ-UADY.

Se estudiaron por conveniencia cuatro UMAs de modalidad intensiva localizadas en la zona centro de Yucatán, México. Las UMAs estudiadas fueron: a) Xmatkuil donde se cría venado cola blanca y pecarí de collar, b) Los Compadres donde se cría pecarí de collar, c) San Juan III donde se cría pecarí de collar, y d) Zoológico del Centenario donde se crían venado cola blanca y venado temazate. En estas UMAs se estudiaron 55 ungulados (14 venados cola blanca, 16 venados temazate y 35 pecaríes de collar). Los muestreos de los animales en
Four intensive modality UMAs, located in the center of Yucatan, Mexico, were studied for convenience. The UMAs studied were: a) Xmatkuil, where white-tailed deer and collared peccary are bred; b) Los Compadres, where collared peccary is bred; c) San J uan III, where collared peccary is bred; and d) Zoológico del Centenario, where white-tailed deer and red brocket deer are bred. In these UMAs, 65 ungulates were studied (14 white-tailed deer, 16 red brocket deer and 35 collared peccaries). Sampling of the animals in captivity was done during the rainy season (August-September).

Deer were captured using remote injection of ketamine:xylacine in a dosage of $4 \mathrm{mg} / \mathrm{kg}: 1.5$ $\mathrm{mg} / \mathrm{kg}$ of live weight, respectively; peccaries were also sedated by remote injection of ketamine in a dosage of $20 \mathrm{mg} / \mathrm{kg}$ of live weight. From each animal, feces were collected directly from the rectum and external examination was done to obtain ectoparasites. Fecal samples, recently excreted from six animals, were directly obtained from the soil of the pens. The feces and ectoparasites were collected, preserved and analyzed by the aforementioned laboratory techniques.

The GIN found in the ungulates studied, were Strongyloides sp and Mammomonogamus sp

Cuadro 1. Género de nematodos gastrointestinales, prevalencia y huevos por gramo de heces encontrados en tres especies de ungulados silvestres bajo condiciones de vida libre en el estado de Yucatán, México

Table 1. Genus of gastrointestinal nematodes, prevalence and number of eggs per gram found in three wild ungulate species under free-living conditions in Yucatan, Mexico

\begin{tabular}{|c|c|c|c|c|}
\hline Animal species & General prevalence (\%) & Gastrointestinal parasites & *Prevalence (\%) & EPG (average) \\
\hline White-tailed deer & & Strongyloides sp* & $3 / 4(75.0)$ & 200.0 \\
\hline (Odocoileus virginianus) & $3 / 4(75.0)$ & Mammomonogamus sp & $2 / 4(50.0)$ & 100.2 \\
\hline Red brocket deer & & Strongyloides sp** & $2 / 3(66.6)$ & 50.0 \\
\hline (Mazama americana) & $2 / 3(66.6)$ & Mammomonogamus sp & $2 / 3(66.6)$ & 183.3 \\
\hline \multicolumn{5}{|l|}{ Collared peccary } \\
\hline (Pecari tajacu) & $3 / 5(60.0)$ & Strongyloides sp & $3 / 5(60.0)$ & 1066.7 \\
\hline
\end{tabular}


condiciones de cautiverio se realizaron durante la época de lluvia (agosto-septiembre).

Los venados se sedaron mediante inyección remota, con una mezcla de ketamina:xilacina a dosis de $4 \mathrm{mg} / \mathrm{kg}: 1.5 \mathrm{mg} / \mathrm{kg}$ de peso vivo, respectivamente para ser capturados; los pecaríes también se sedaron por inyección remota de ketamina, con una dosis de $20 \mathrm{mg} /$ $\mathrm{kg}$ peso vivo. De cada animal se colectó excremento directamente del recto y se realizó la inspección externa para la búsqueda y obtención de ectoparásitos. Las muestras fecales recién excretadas de seis animales se obtuvieron directamente del suelo de los corrales. El excremento y los ectoparásitos fueron colectados, conservados y analizados mediante las pruebas de laboratorio ya descritas.

Los NGI encontrados en los ungulados estudiados fueron Strongyloides sp y Mammomonogamus sp (Cuadro 1). En estos animales también se encontraron garrapatas (Amblyomma cajennense), pulgas (Pulex irritans), moscas (Lipoptena sp) y piojos (Gliricola porcelli) (Cuadro 2).

En los ungulados estudiados se encontraron los siguientes PGI: nematodos (Strongyloides sp,
(Table 1). There were also ticks (Amblyomma cajennese), fleas (Pulex irritans), flies (Lipoptena $\mathrm{sp})$ and lice (Gliricola porcelli) (Table 2).

The following gastrointestinal parasites were found in the ungulates studied: nematodes (order Strongyloides sp, Capillaria sp, Trichuris $\mathrm{sp}$ and the Strongylida) and protozoans of the order Eucoccidiorida. In larval culture of the order Strongylida, from collared peccaries, the genus Oesophagostomum was identified.

In oocyst cultures of the order Eucoccidiorida, from ungulates in captivity, the following genera were identified: a) white-tailed deer: Eimeria, b) red brocket deer: Eimeria, and c) collared peccaries: Eimeria and Isospora. No external parasites were recovered on external examination of wild animals in captivity (Table 3 ).

In the present study, ungulates kept in captivity showed greater number (five) of genera of gastrointestinal parasites and higher average excretion of eggs per gram (EPG), in comparison to free-living ungulates (three genera). This behavior is similar to that observed by Prestwood and Pursglove(5), who reported that enclosed high deer densities have the potential to increase transmission of gastrointestinal

Cuadro 2. Género y especie de ectoparásitos encontrados en tres especies de ungulados silvestres bajo condiciones de vida libre en el estado de Yucatán, México

Table 2. Genus and species of ectoparasites found in three wild ungulate species under free-living conditions in the State of Yucatan, Mexico

\begin{tabular}{lcccc}
\hline Animal species & $\begin{array}{c}\text { General } \\
\text { prevalence }(\%)\end{array}$ & $\begin{array}{c}\text { Type of } \\
\text { ectoparasite }\end{array}$ & Genus or species & *Prevalence \\
\hline White-tailed deer & $4 / 4(100.0)$ & Fly & Lipoptena sp & $4 / 4(100.0)$ \\
(Odocoileus virginianus) & & Tick & Amblyomma cajennense & $4 / 4(100.0)$ \\
Red brocket deer & \multirow{2}{*}{$3 / 3(100.0)$} & Tick & Amblyomma cajennense & $3 / 3(100.0)$ \\
(Mazama americana) & & Flea & Pulex irritans & $2 / 3(75.0)$ \\
& & Louse & Gliricola porcelli & $3 / 3(100.0)$ \\
Collared peccary & $5 / 5(100.0)$ & Tick & Amblyomma cajennense & $5 / 5(100.0)$ \\
(Pecari tajacu) & & Flea & Pulex irritans & $4 / 5(80.0)$ \\
& & Louse & Gliricola porcelli & $3 / 5(60.0)$ \\
\hline
\end{tabular}

* By genus of parasite. 
Capillaria sp, Trichuris sp y el orden Strongylida) y protozoos del orden Eucoccidiorida. En los cultivos de larvas del orden Strongylida de los pecaríes de collar, se identificó el género Oesophagostomum.

En los cultivos de ooquistes del orden Eucoccidiorida proveniente de ungulados en condiciones de cautiverio, se identificaron los siguientes géneros: a) venados cola blanca: Eimeria, b) venados temazate: Eimeria, y c) pecaríes de collar: Eimeria e Isospora. No se recuperaron parásitos externos en la inspección de los animales silvestres en condiciones de cautiverio (Cuadro 3 ).

En el presente estudio los ungulados mantenidos en cautiverio presentaron mayor número (cinco) de géneros de parásitos gastrointestinales y promedio de excreción de $\mathrm{h} / \mathrm{gh}$ comparados con ungulados de vida libre (tres géneros). Este comportamiento es similar a lo encontrado por Prestwood y Pursglove(5) quienes reportaron que la alta concentración de venados en cautiverio aumenta la transmisión de PGI al parasites through consumption of highly contaminated vegetation.

Four genera of gastrointestinal parasites in whitetailed deer and red brocket deer were identified: Strongyloides, Trichuris, Capillaria and Eimeria. These genera have been reported in whitetailed deer in Yucatan, Mexico(21). In Brazil, Lux et al(22) studied the helminths that affect the gray-brown brocket deer (Mazama gouazoubira) and reported eight GIN species where they included the genus Capillaria; however, the genus Haemonchus was the most important.

Other researchers $(21,23)$ mention that $\mathrm{GIN}$ and protozoans of the order Eucoccidiorida (Eimeria) in deer and domestic ruminants may cause growth retardation, weakness, anemia, decrease of resistance to other conditions and decreased appetite. The pathogenicity of genus Eimeria is due to its reproductive capacity and intestine destruction $(19,23)$. In the present study it was found that ungulates excrete 70 to 323 protozoan oocysts/g of feces (OPG) of the order

Cuadro 3. Género y orden de nematodos gastrointestinales y protozoos del orden Eucoccidiorida, prevalencia y huevos por gramo de heces encontrados en tres especies de ungulados silvestres bajo condiciones de cautiverio en Yucatán, México

Table 3. Genus and order of gastrointestinal nematodes and protozoans of the order Eucoccidiorida, prevalence and number of eggs per gram found in three wild ungulate species in captivity in Yucatan, Mexico

\begin{tabular}{lclc}
\hline Animal species & Prevalence $(\%)$ & Gastrointestinal parasites & $\begin{array}{c}\text { Average of } \\
\text { EPG or OPG }\end{array}$ \\
\hline White-tailed deer & $5 / 14$ & Strongyloides sp & 200.0 \\
(Odocoileus virginianus) & $(35.7)$ & $\begin{array}{l}\text { Capillaria sp } \\
\text { Eucoccidiorida (Eimeria) }\end{array}$ & 80.0 \\
& & Eucoccidiorida (Eimeria) & 130.0 \\
Red brocket deer & $5 / 16$ & Trichuris $s p$ & 70.0 \\
(Mazama americana) & $(31.2)$ & Strongyloides sp & 50.0 \\
Collared peccary & $22 / 35$ & Eucoccidiorida (Eimeria, Isospora) & 209.0 \\
(Pecari tajacu) & $(62.8)$ & Strongylida (Oesophagostomum) & 125.2 \\
& & &
\end{tabular}

EPG: Number of eggs per gram.

OPG: Number of oocysts per gram. 
incrementarse la ingestión de parásitos en la vegetación que es consumida por los animales.

En venados cola blanca y temazate en condiciones de cautiverio se identificaron cuatro géneros de PGI (Strongyloides, Trichuris, Capillaria y Eimeria). Estos géneros han sido reportados en venados cola blanca de Yucatán, México(21). En un estudio realizado en Brasil por Lux et al(22) estudiaron los helmintos que afectan al venado corzuela parda (Mazama gouazoubira) y reportaron ocho especies de NGI donde incluyeron al género Capillaria; sin embargo, el género Haemonchus fue el más importante.

Otros investigadores(21,23) mencionan que en venados y en rumiantes domésticos, los NGI y los protozoos del orden Eucoccidiorida (Eimeria) pueden ocasionar retraso en el crecimiento, debilidad, anemia, disminución de la resistencia a otros padecimientos y reducción del apetito. La patogenicidad del género Eimeria se debe a su capacidad de reproducción y destrucción de gran cantidad de células intestinales $(19,23)$. En el presente estudio se encontró que los ungulados excretan de 70 a 323 ooq/gh protozoos del orden Eucoccidiorida y de 50 a 1,066.7 h/gh de NGI. Estos valores de excreción se consideran bajos en comparación con los rumiantes domésticos tales como ovinos y caprinos de Yucatán, México(16); sin embargo, es necesario realizar estudios más precisos para conocer el efecto de estos parásitos gastrointestinales sobre la producción de los ungulados.

La presencia de un mayor número de géneros de parásitos gastrointestinales y un mayor promedio de excreción de $\mathrm{h} / \mathrm{gh}$ en los ungulados mantenidos en cautiverio, pudo deberse a que los animales generalmente consumen alimentos directo del piso y a la presencia de mayor humedad en condiciones de cautiverio (formación de charcas, fuga de agua de bebederos, etc.). Esta situación pudo propiciar un mejor desarrollo de los helmintos y coccidias en sus fases no parásitas, y por ende en una
Eucoccidiorida and 50 to 1,066.7 nematode eggs per gram of feces. These excretion values are considered low in comparison with other domestic ruminants, such as sheep and goats in Yucatan, Mexico(16); however, it is necessary to conduct more precise studies to ascertain the effect of these gastrointestinal parasites on ungulate production.

The presence of greater number of genera of gastrointestinal parasites and higher average of eggs/gram of feces in ungulates kept in captivity may be because animals usually eat food from the floor and also to the presence of higher humidity under captive conditions (pool formation, water leakage, etc.). This situation favored the development of helminths and coccidia into nonparasitic stages, and therefore, greater risk of infection. On the other hand, wild animals have huge feeding areas that favor little contact between animals and parasites(19,23).

The present study reports for the first time the presence of genus Mammomonogamus parasitizing white-tailed deer and red brocket deer in Yucatan, Mexico. The Mammomonogamus laryngeus species is a nematode usually present in the larynx of mammals of the tropics, including deer. Dominguez-Alpizar et a/(24) reported for the first time the presence of $M$. laryngeus parasitizing bovines in Yucatan, Mexico. In Colombia it is reported as a zoonosis that is transmitted by domestic mammalian animals and wild animals to humans(25).

There is little information about gastrointestinal parasites that affect the collared peccary. The genera Eimeria, Strongyloides and Oesophagostomun identified in the present study, have been already reported in peccaries from other countries $(9,26-28)$. It is agreed that gastrointestinal parasites cause anorexia, decreased appetite, loss of blood and plasma proteins in the gastrointestinal tract, alterations on protein metabolism, reduction of minerals, depression of the activity of some intestinal enzymes and diarrhea $(19,29)$; however, the effect of parasites on the health of the peccaries is unknown. 
mayor posibilidad de infección. Por el contrario, los animales en vida silvestre tienen zonas amplias donde alimentarse lo que favorece el menor contacto de los animales y sus parásitos $(19,23)$.

En el presente estudio se reporta por primera vez en Yucatán, México la presencia del género Mammomonogamus parasitando venados cola blanca y temazate. La especie Mammomonogamus laryngeus es un parásito nematodo que suele encontrarse en la laringe de mamíferos del trópico, incluyendo al venado. En Yucatán, México, Domínguez-Alpizar et a/(24) reportaron por primera vez la presencia de $M$. laryngeus parasitando bovinos. En Colombia es reportada como una zoonosis que es transmitida de los animales mamíferos domésticos y silvestres al humano(25).

Existe poca información sobre los PGI que afectan al pecarí de collar. Los géneros Eimeria, Strongyloides y Oesophagostomun identificados en el presente estudio, han sido previamente reportados en pecaríes de otros países $(9,26-28)$. Es reconocido que los PGI causan en los cerdos anorexia, reducción en la ingestión de alimentos, pérdidas de sangre y proteínas plasmáticas en el tracto gastrointestinal, alteraciones en el metabolismo proteico, reducción de minerales, depresión en la actividad de algunas enzimas intestinales y diarrea $(19,29)$; sin embargo, el efecto de los parásitos sobre la salud de los pecaríes no se conoce con precisión.

Wilber et a/(9) colectaron excremento fresco de pecaríes de collar cazados en un área de manejo de vida silvestre en Texas, USA e identificaron cuatro especies de Eimeria (E. chaparralensis, E. dicotylensis, E. pecari y Eimeria $\mathrm{sp}$ ), reportando que $E$. pecari es la especie más común ( $45 \%$ de los animales estudiados); sin embargo, no identificaron el género Isospora que es reportado en el presente estudio. En futuros estudios es necesario estudiar si el género Isospora afecta a los pecaríes 0 probablemente afecte otras especies animales.
Wiber et al(9) collected fresh feces from collared peccaries hunted in a wildlife management area in Texas, USA and identified four Eimeria species (E. chaparralensis, E. dicotylensis, E. pecari and Eimeria sp), reporting that $E$. pecari is the most common species ( $45 \%$ of the animals studied); however, they did not identify the genus Isospora that is reported in the present study. It is important to study whether the peccary is the only species affected by the genus Isospora or if it affects other animal species.

In the present study it was found that Pulex irritans (The Human Flea) and Gliricola porcelli (louse) parasitize red brocket deer and collared peccary. Many fleas have the capacity to parasitize different hosts and the genus Pulex has the capacity to parasitize different wild animal species in South America(10,30). The importance of $P$. irritans in wild animals lies in the damage that causes while feeding on its hosts and to serve as reservoir so that humans will get infested. This flea has been reported in North America as a vector of Rickettsia typhi and $R$. felis, and bacteria, such as Bartonella henselae(31). The only fly described in the present study (Lipoptena sp) was collected from white-tailed deer. This fly is generally found feeding on blood from deer causing discomforts. L. depressa has been reported in North America and $L$. cervi in Europe and North America(19).

In this study, the tick $A$. cajennese was found parasitizing the three ungulate species studied. This tick species often parasitizes humans and may transmit Rickettsia rickettssi(32-34). In Yucatan, Mexico, this tick parasitizes several domestic animal species, such as: cattle, dogs, horses, including man(29). In Brazil(11), it is mentioned that $A$. cajennese is the most abundant in deer and is responsible for the transmission of $R$. rickettssi to man. In Yucatan, Mexico, Rodríguez-Vivas et a/(35) recently reported the presence of $A$. cajennese in red deer, representing $3 \%$ of tick infestations.

It is concluded that wild ungulates are parasitized with GIN (Strongyloides, Trichuris, Capillaria, 
En el presente estudio se encontró que la pulga Pulex irritans y el piojo Gliricola porcelli parasitan al venado temazate y pecarí de collar. Muchas pulgas tienen la capacidad de parasitar diferentes hospederos y el género Pulex tiene la capacidad para parasitar diferentes especies de animales silvestres en Sudamérica $(10,30)$. La importancia de P. irritans en los animales silvestres radica en el daño que produce al alimentarse de sus hospederos y de servir como reservorio para que los humanos se infesten. Esta pulga ha sido reportada en Norteamérica como transmisora de Rickettsia typhi and $R$. felis, y de bacterias tales como Bartonella henselae(31).

La única mosca descrita en el presente estudio (Lipoptena sp) se colectó de venados cola blanca. Esta mosca es común encontrarla alimentándose de sangre de venados y causándoles malestares. L. depressa ha sido reportada en Norteamérica, y L. cervi en Europa y Norteamérica(19).

En el presente estudio la garrapata $A$. cajennese se encontró parasitando a las tres especies de ungulados estudiados. Esta especie de garrapata suele parasitar al humano y puede transmitirle Rickettsia rickettssi(32-34). En Yucatán, México esta especie de garrapata parasita a varias especies de animales domésticos tales como el bovino, perro, equinos, incluyendo al hombre(29). En Brasil(11) mencionan que $A$. cajennense es la especie más abundante en el venado y es la responsable en la transmisión de $R$. rickettssi al humano. En Yucatán, México, recientemente Rodríguez-Vivas et al(35) reportaron la presencia de $A$. cajennense en ciervos rojos representando el $3 \%$ de las infestaciones por garrapatas.

Se concluye que los ungulados silvestres se encuentran parasitados con NGI (Strongyloides, Trichuris, Capillaria, Mammomonogamus y Oesophagostomun), protozoos del orden Eucoccidiorida (Eimeria e Isospora), pulgas ( $P$. irritans), piojos (G. porcelli), moscas (Lipoptena sp) y garrapatas ( $A$. cajennese). La
Mammomonogamus and Oessophagostomun), protozoans of the order Eucoccidiorida (Eimeria and Isospora), fleas ( $P$. irritans), lice ( $G$. porcelli), flies (Lipoptena sp) and ticks ( $A$. cajennese). The importance of the parasites identified in wild ungulates under free-living and captive conditions in Yucatan, Mexico is that they are pathogen agents and there is risk of transmission of these parasites to other domestic animals and humans. For a better understanding of this parasitosis, continuous monitoring of freeliving and captive wild animals is necessary to assess the magnitude of the problem for steering prevention and control programs on parasites in wild fauna.

End of english version

importancia de los parásitos identificados en los ungulados silvestres en condiciones de vida libre y cautiverio en Yucatán, México radica en que son agentes patógenos, y existe el riesgo de la transmisión de estos parásitos a otros animales domésticos y al hombre. Para un mejor entendimiento de estas parasitosis, en necesario continuar el monitoreo de animales en estado silvestre y en cautiverio, para conocer la magnitud del problema y en su caso orientar los programas de prevención y control de parásitos en la fauna silvestre.

\section{LITERATURA CITADA}

1. Naranjo EJ, Bodmer RE. Source-sink systems and conservation of hunted ungulates in the Lacandon Forest, Mexico. Biol Conserv 2007; 138:412-420.

2. Jorgenson JP. Maya subsistence hunters in Quintana Roo, Mexico. Oryx 1995;29:49-57.

3. Naranjo EJ. Population ecology and conservation of ungulates in the Lacandon Forest, Mexico [Ph.D. Dissertation]. University of Florida, Gainesville. 2002.

4. Schultz SR, Barry RX, Johnson MK, Miller JE, Forbes DA. Effects of feed plots on fecal egg counts of white-tailed deer. Small Ruminant Res 1994;13:93-97.

5. Prestwood AK, Pursglove SR. Gastrointestinal nematodes. In: Davidson WR, et al editors. Diseases and parasites of 


\section{PARÁSITOS GASTROINTESTINALES Y ECTOPARÁSITOS DE UNGULADOS SILVESTRES}

white-tailed deer. Tall Timbers Res Sta Misc Publ 7, Tallahassee, Florida, USA. 1981;318-350.

6. Davidson WR, McGhee MB, Nettles VF, Chappell LC. Haemonchosis in white-tailed deer in the southeastern. United States. J Wild Dis 1980;16:499-508.

7. Conti JA, Howerth EW. Osteragiosis in a white-tailed deer due to Ostertagia. J Wild Dis 1987;23:159-162.

8. Pato FJ, Vázquez L, Díez-Baños N, López C, SánchezAndrade R, Fernández G, et al. Gastrointestinal nematode infections in roe deer (Capreolus capreolus) from the NW of the Iberian Peninsula: Assessment of some risk factors. Vet Parasitol 2013;196(1-2):136-142.

9. Wilber P, Hellgren E, Gabor T. Coccidia of the collared peccary (Tayassu tajacu) in southern Texas with descriptions of three new species of Eimeria (Apicomplexa: Eimeriidae). J Parasitol 1996;82:624-629.

10. Torres-Mejía AM, de la Fuente J. Risks associated with ectoparasites of wild mammals in the department of Quindío, Colombia. Intern J Appl Res Vet Med 2006;4(3): 187-192.

11. Szabó MPJ, Castro MB, Ramos HGC, Garcia MV, Castagnolli $\mathrm{KC}$, Pinter $A$, et al. Species diversity and seasonality of free-living ticks (Acari: Ixodidae) in the natural habitat of wild Marsh deer (Blastocerus dichotomus) in Southeastern Brazil. Vet Parasitol 2007;143:147-154.

12. González RM. Diagnóstico de situación de las unidades para la conservación, manejo y aprovechamiento sustentable de fauna silvestre (UMAS), en el estado de Yucatán México [tesis licenciatura]. Universidad Autónoma de Yucatán. Mérida, Yucatán, México. 2002.

13. Instituto Nacional de Estadística, Geografía e Informática, INEGI. Climatología del estado de Yucatán. Anuario estadístico del Estado de Yucatán. INEGI. Gobierno del estado de Yucatán. 1996.

14. Bautista F, Batllori E, Palacio G, Ortiz M, Castillo M. Integración del conocimiento actual sobre los paisajes geomorfológicos de la península de Yucatán. En: Caracterización y manejo de los suelos de la península de Yucatán. Implicaciones agropecuarias, forestales y ambientales. Bautista, F, Palacio AG editores. Universidad Autónoma de Campeche/ Universidad Autónoma de Yucatán/ Instituto Nacional de Ecología, México, D.F. 2005;33-58.

15. Flores S, Espejel I. Tipos de vegetación de la Península de Yucatán. Serie Etnoflora Yucatanense, fascículo 3, Universidad Autónoma de Yucatán y Universidad de California, Mérida. 1994.

16. Rodríguez-Vivas RI, Cob-Galera LA. Técnicas diagnósticas en parasitología veterinaria. Segunda edición. Universidad Autónoma de Yucatán. Mérida, México. 2005.

17. Tentera AM, Bartab JR, Beveridgec I., Duszynskid DW, Mehlhorne $\mathrm{H}$, Morrisonf DA, et al. The conceptual basis for a new classification of the coccidia. Int J Parasitol 2002; 32:595-616.

18. Ministry of Agriculture Fisheries and Food (MAFF). Manual of Veterinary Parasitological Laboratory Techniques. Reference Book 418. Her Majesty's Stationary Office, London. 1986;159.

19. Taylor MA, Coop RL, Wall RL. Veterinary Parasitology. Third ed. Oxford, UK Blackwell Publishing; 2007.

20. Wall R, Shearer D. Veterinary ectoparasites, biology, pathology and control. 2nd, ed. London, UK: Blackwell Science; 2001.
21. Montes PRC, Rodríguez-Vivas RI, Torres AFJ, Ek PLG. Seguimiento anual de la parasitosis gastrointestinal de venados cola blanca Odocoileus virginianus (Artiodactyla: Cervidae) en cautiverio en Yucatán, México. Rev Biol Trop 1988;46(39):821-827.

22. Lux Hoppe EG, Tebaldi JH, Nascimento AA. Helminthological screening of free-ranging grey brocket deer Mazama gouazoubira Fischer, 1817 (Cervidae: Odocoileini) from Brazilian Pantanal wetlands, with considerations on Pygarginema verrucosa (Molin, 1860) Kadenatzii, 1948 (Spirocercidae: Ascaropsinae). Braz J Biol São Carlos 2010; 70(2):417-423.

23. Rodríguez-Vivas RI, Ojeda-Chi MM, Pérez-Cogollo LC, Rosado-Aguilar JA, Ramírez-Cruz GT, Guemes-Ceballos AA. Epidemiología, diagnóstico y control de la coccidiosis bovina. En: Epidemiología de enfermedades parasitarias en animales domésticos. Quiroz RH, et al editores. AMPAVE. México, D.F. 2011;52-66.

24. Domínguez-Alpizar J L, Rodríguez-Vivas RI, Honhold N. Epizootiología de los parásitos gastrointestinales en bovinos del estado de Yucatán. Vet Méx 1993;24(3):189-193.

25. Castaño JC, Núñez FA, González MM, Téllez G, Giraldo MI. Reporte del primer caso humano de infección parasitaria por Mammomonogamus laryngeus en Colombia. Bioméd 2006;26(3):337-341.

26. Fowler ME. Cría y patología de los pecaris y los suidos salvajes en cautividad. Revista Científica y Técnica. Paris, Francia. Editorial OIE. 1996;15:1.

27. Sowls L. Javelinas and other peccaries their biology, management and use. 2nd ed. Tucson Arizona, USA. 1997.

28. Vicente JJ, Rodrigues HO, Gomes DC, Pinto RM. Nematóides do Brasil. Parte V. Nematóides de mamíferos. Rev Bras Zool 1997;14(Supl 1):441-452.

29. Rodríguez-Vivas RI, Ramírez-Cruz GT, Quiñones-Avila FJ. Epidemiología, prevención control de la coccidiosis porcina. En: Rodríguez VRI editor. Enfermedades de importancia económica en producción animal. México, D.F. McGrawHill-UADY. 2005.

30. Durden LA, Cunningham MW, McBride R. Ectoparasites of free-ranging pumas and jaguars in the Paraguayan Chaco. Vet Parasitol 2006;137:189-193.

31. Azad, AF, Radulovic S, Higgins, JA, Noden BH, Troyer JM. Flea-borne rickettsioses: Ecologic considerations. Emerg Infect Dis 1997;3:319-327.

32. Guedes E, Leite RC, Prata MCA, Pacheco RC, Walker DH, Labruna B. Detection of Rickettsia rickettsii in the tick Amblyomma cajennense in a new Brazilian spotted feverendemic area in the state of Minas Gerais. Mem Inst Oswaldo Cruz 2005; 100:841-45.

33. Sangioni LA, Horta MC, Vianna MCB, Gennari SM, Soares RM, Galvao MAM, et al. Rickettsial infection in animals and Brazilian spotted fever endemicity. Emerg Infect Dis 2005; 11(2):255-270.

34. Oliveira KA, Pinter A, Medina-Sanchez A, Boppana VD, Wikel SK, Saito TB, et al. Amblyomma imitator ticks as vectors of Rickettsia rickettsii, Mexico. Emerg Infect Dis 2010;16(8): 1282-1284.

35. Rodríguez-Vivas RI, Ojeda-Chi MM, Rosado-Aguilar JA, Trinidad-Martínez IC, Torres-Acosta J FJ, Ticante-Perez V, et al. Red deer (Cervus elaphus) as a host for the cattle tick Rhipicephalus microplus (Acari: Ixodidae) in Yucatan, Mexico. Exp Applied Acarol 2013;60(4):543-552. 
